\title{
Karstification Effect on the Stability of Mosul Dam and Its Assessment, North Iraq
}

\author{
Varoujan K. Sissakian ${ }^{1}$, Nadhir Al-Ansari ${ }^{2 *}$, Sven Knutsson ${ }^{2}$ \\ ${ }^{1}$ Consultant Geologist, Erbil, Iraq \\ ${ }^{2}$ Lulea University of Technology, Lulea, Sweden \\ Email: varoujan49@yahoo.com, ․ㅡadhir.alansari@ltu.se, Sven.Knutsson@ltu.se
}

Received January 1, 2014; revised February 1, 2014; accepted February 8, 2014

Copyright (c) 2014 Varoujan K. Sissakian et al. This is an open access article distributed under the Creative Commons Attribution License, which permits unrestricted use, distribution, and reproduction in any medium, provided the original work is properly cited. In accordance of the Creative Commons Attribution License all Copyrights (C) 2014 are reserved for SCIRP and the owner of the intellectual property Varoujan K. Sissakian et al. All Copyright (C) 2014 are guarded by law and by SCIRP as a guardian.

\begin{abstract}
Mosul Dam is located on the Tigris river, $50 \mathrm{Km} \mathrm{NW}$ of Mosul; it is $113 \mathrm{~m}$ in height, $3.4 \mathrm{Km}$ in length, $10 \mathrm{~m}$ wide in its crest and has a storage capacity of $\mathbf{1 1 . 1}$ billion cubic meters. It is an earth fill dam, constructed on bedrocks of Fat'ha Formation, which consists of gypsum beds alternated with marl and limestone, in cyclic nature. The thickness of gypsum beds attains $18 \mathrm{~m}$; they are intensely karstified even in foundation rocks. Therefore, continuous grouting Programme was planned during construction, which was completed in June 1984, with planned operation age of 80 years. Due to insufficient grouting in the foundation, during last years of the last century, the Karstification was enlarged in size and quantity, causing serious problems to the stability of the dam. Since late eighties of the last century, the status of the dam and its probable collapse has caused a panic to the people of Mosul city and near surroundings. Therefore, many attempts were carried out for assessment of the dam; all of them concluded that the Karstification is the main problem and recommended continuous grouting, using modern techniques. In addition, the authorities started to build another "Badush Dam" south of Mosul Dam so that it can stop the first wave if Mosul Dam if collapsed. All geophysical and geological work executed on the dam site; it concluded that the existence of many weaknesses zones, faults and large karstified areas, in different parts of the dam site.
\end{abstract}

\section{KEYWORDS}

Mosul Dam; Karstification; Sink Hole; Iraq

\section{Introduction}

Mosul Dam is located on the Tigris River in northern Iraq approximately $50 \mathrm{~km}$ northwest of Mosul city and $80 \mathrm{Km}$ from Syria and Turkey (Figure 1). It is $113 \mathrm{~m}$ in height, $3.4 \mathrm{Km}$ in length, $10 \mathrm{~m}$ wide in its crest and has a storage capacity of 11.1 billion cubic meters [1]. It is an earth fill dam, constructed on bedrocks of Fat'ha Formation, which consists of gypsum beds alternated with marl and limestone, in cyclic nature. The thickness of gypsum beds attains $18 \mathrm{~m}$; they are intensely karstified even in foundation rocks. It is a multipurpose project for irrigation, flood control and hydropower generation. The majority of the water entering the reservoir flows from the

\footnotetext{
"Corresponding author.
}

River Tigris. The water surface area of the reservoir at the beginning of the dam operation was $380 \mathrm{~km}^{2}$ with a storage capacity of $11.11 \times 10^{9} \mathrm{~m}^{3}$ at the maximum operation level 330 m.a.s.l including $8.16 \times 10^{9} \mathrm{~m}^{3}$ live storage and $2.95 \times 10^{9} \mathrm{~m}^{3}$ dead storage [2].

The construction of the dam started in 1980 and completed in June, 1984 with the initial filling of the reservoir during the following spring [3]. The majority of the water entering the reservoir flows from Turkey. The dam functions for flood control, irrigation, and power supply providing Mosul with the majority of its power [4].

Mosul dam was a matter of debate since its operation in 1984 due to its critical status caused mainly by karstification, which is one of the well-known geological hazards, not only in the concerned area but in many other 


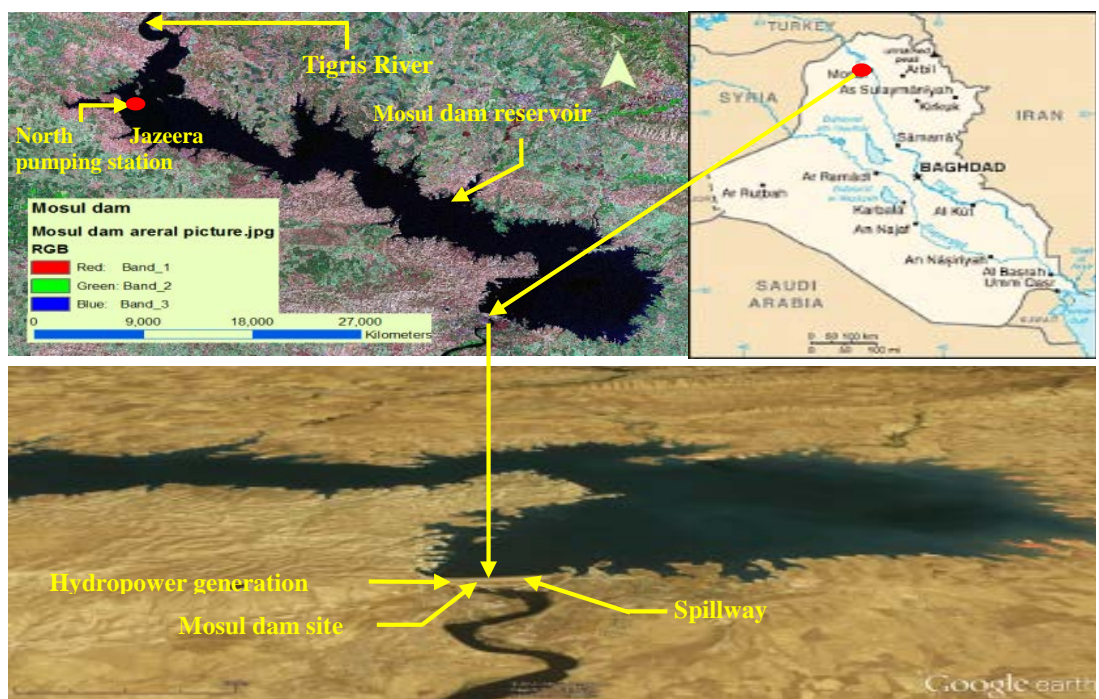

Figure 1. Location of the Mosul Dam.

large areas in different parts of Iraq [5]. The first awesome about its failure was in 1987, since that time, many rumors caused panic for the inhabitants of Mosul city and near surroundings. Officially, enormous attempts were carried out to overcome the existing problems and to keep the dam in a safe status. Among them are the assessment of the dam by well expertised and specialized firms, their submitted reports are the main source of data, which was used in concluding this study. It is worth mentioning that the seven reports were submitted to the Iraq Geological Survey (GEOSURV) by the authorities of Mosul Dam Operation Office, during executing the geophysical surveys in 2006 and 2007. Two geophysical reports concluded by GEOSURV geophysicist and all other relevant data in GEOSURV's archive were used to. The aim of this study is to elucidate the effect of the geological hazards on the stability of the Mosul Dam and to discuss them. Moreover, to mention the results from the inspections that was carried out by specialized firms on the stability of the dam.

\section{Previous Studies}

The following activities were carried out by the Iraq Geological Survey (GEOSURV) and others concerning the study at the site and related aspects:

- Tawfiq and Domas [6] mapped the dam site area within the Regional Geological mapping of Iraq. They mentioned that the dam site was built up by the Upper Member of Fatha Formation (Middle Miocene), which consists of marl, limestone and gypsum in rhythmic cycles, with red claystone, siltstones and sandstones in the upper cycles. The limestone and gypsum beds are intensely karstified. However, the near surroundings are built up by the Lower Member of Fatha Formation, which consist of the same rock types, except the absence of red claystones, siltstone and sandstone. The gypsum and limestone layers of the Lower Member are much more karstified than those of the Upper Member, which means that the rocks for the foundation of the dam are much more karstified. Many faults were detected in the dam site area, besides the Sinjar-Dohuk-Amadiay deep seated fault that crosses the dam site.

- Al-Ansari et al. [5] conducted detailed geological and geophysical investigations on the dam site area. Two major faults extending from the north to the south and crossing the dam axis were reported. In addition the boundary condition on the model which was suggested by the consultant was found inapplicable.

- Sissakian and Ibrahim [7] reported about geological hazards of Mosul Quadrangle, scale 1:250,000 and mentioned that the Mosul dam site area is under the influence of karstification and zoned it as Medium Term of Occurrence, scoring 5.5 degrees.

- Hijab and Al-Jabbar [8] conducted different geophysical measurements in the dam site. They detected many weakness zones and intensely karstified areas, with a probable fault running along the dam axis.

- Hijab et al. [9], conducted geophysical measurements in the dam site, as second stage. They located many weakness zones in depth of about $50 \mathrm{~m}$ and different karstified areas.

In 1983, GEOSURV contributed in detailed geological mapping of the dam site. Many faults were mapped along the dam site with different directions. Unfortunately, the report is not documented in GEOSURV's library.

\section{Characteristics of Mosul Dam}

Mosul Dam is one of the most important and strategic projects in Iraq. It is a multipurpose project. One of its 
functions is to provide water at a rate of $48 \mathrm{~m}^{3} / \mathrm{sec}$ for a huge irrigation project known as "North Al-Jazira Irrigation project" that covers an area of $625 \mathrm{~km}^{2}$. This station is located in the upper zone of the Mosul reservoir dam [10-12]. The characteristics of the dam are mentioned hereinafter.

The main body of the dam is $113 \mathrm{~m}$ high; $3.4 \mathrm{~km}$ long zoned with earth fill embankment, a powerhouse, bottom outlet, concrete-lined gated spillway, and a fuse plug secondary spillway. The total volume of material for the embankment is reported to be around 37.7 million $\mathrm{m}^{3}$. The upstream and downstream embankment slopes are inclined 2.5:1 (horizontal: vertical) below El. $330 \mathrm{~m}$, which is the normal high operating pool level. Above El. 330 meters, both slopes are inclined at 1.73:1. There are also 4:1 toe berms constructed against both the upstream and downstream slopes. The berms were included to provide adequate stability against potential sliding on a clay layer identified with the foundation of the dam [13]. The embankment of the main dam has a crest elevation of $343 \mathrm{~m}$ and width of $10 \mathrm{~m}$. The minimum operating pool elevation is $300 \mathrm{~m}$, with a maximum of $330 \mathrm{~m}$ (the elevation of the spillway channel overflow is $317.5 \mathrm{~m}$ ). Active storage is around 8.1 billion cubic meters and total storage at a maximum pool is 11.1 billion cubic meters. The maximum discharge of the spillway is $12,400 \mathrm{~m}^{3} / \mathrm{s}$ at a maximum pool level [14]. However, the Mosul reservoir storage capacity was reduced by 1.143 $\mathrm{km}^{3}$ due to sedimentation during the period of 1986-2011, whereas the original capacity was $11.11 \mathrm{~km}^{3}$. This suggests an average annual sedimentation rate of $45.72 \times 10^{6}$ $\mathrm{m}^{3} \cdot \mathrm{yr}^{-1}$. Most of the sediments were deposited within the northern zone of the reservoir where the River Tigris entrance is located [15]. The rate of reduction in volume capacity decreases gradually from in the northern zone (7.74\%), to the middle zone (3.87\%) and then to the southern zone (3.12\%) [10]. Moreover, according to Issa et al. [16], the storage capacity of Mosul Reservoir at pool elevation of $320 \mathrm{~m}$ a.s.l was $7.749 \times 10^{9} \mathrm{~m}^{3}$ for the original operation curve and $6.606 \times 10^{9} \mathrm{~m}^{3}$ for the 2011 survey, giving a difference in storage capacities of 1.143 $\times 10^{9} \mathrm{~m}^{3}$. This represents the total storage loss due to sediment deposition throughout the operational period, and represents $14.73 \%$ of total storage.

The design of the dam was done by a consortium of experienced, respected and well-known European consultants, Swiss Consultants group, comprise:

- Motor Columbus;

- Electrowatt;

- Suiselectra;

- Societe Generale pour l'Industrie.

The construction was carried out by a German-Italian consortium of experienced international contractors, GIMOD joint venture, comprising:
- Hochtief;

- Impregilo;

- Zublin;

- Tropp;

- Italstrade;

- Cogefar.

The consultants for supervision comprised a joint venture of Swiss Consultants Group and Energo-Projekt of Yugoslavia, known as MODACON.

An international board of experts was convened to review the work in progress. The board included members with international reputations although its structure changed during the project $[3,4]$.

\section{Geologic Setting}

The hereinafter generalized geological data are quoted from Sissakian et al. [17]) and Sissakian [18]. The geology of the area surrounding the dam site consists of Pleistocene to Recent age alluvial deposits overlying rocks of the Middle Miocene age Fatha Formation (exLower Fars Formation) (the principal foundation rocks below the dam causing the major concerns) and the Early Miocene age Jeribe Formation. The lower terraces of the river have sandy, clayey silt up to $20 \mathrm{~m}$ thick which was used for constructing the core of the dam. Some alluvium is present at elevations over $80 \mathrm{~m}$ above the present valley floor, indicative of major climatic variations.

The foundation geology of the dam comprises of a layered sequence of rocks, including marls, chalky limestone, gypsum, anhydrite, and limestone. A feature of the geology is the occurrence of karstic limestone and the development of solution cavities within the gypsum and anhydrite layers. Four significant gypsum units were identified during design and construction varying in thickness from 8 to $6 \mathrm{~m}$. The dissolution and erosion of gypsum by water seeping under the dam is believed to be the main cause to the development of voids requiring continuous grouting [14].

The dam site is located within Butmah East anticline, which is almost E-W trending with steeper southern limb. Many faults occur in the concerned area, besides the Sinjar-Dohuk-Amadiya deep seated fault [6]. The dam site is considered as one of the main karstified areas in Iraq, with effective geological hazard, due to existence of karstified thick gypsum beds. The karstification, in ranking of the existing geological hazards has scored 5.5 degrees [7].

\section{Karstification}

Karstification is a main problem in gypsum and limestone beds of the Fatha Formation, not only in the Mosul dam site but almost everywhere in its exposers. Many structures suffer from the karstification in Iraq; damages 
of different sizes have occurred and still are occurring [19].

Erosion and dissolution rates in gypsum are related to the seepage velocities and hydraulic gradient. A review of case histories dealing with gypsum show that gypsum dissolution occurs until seepage water reaches a calcium sulfate saturation of approximately 2000 ppm [13]. The dissolution zone moves downstream as greater quantities of unsaturated water attack a gypsum bed. At Mosul dam, major dissolution occurs at the "karstic line," the inferred boundary where anhydrite converts to gypsum, and this unit is subsequently dissolved and eroded by seepage. The dissolution of evaporites by groundwater is a common phenomenon and the void is generally filled with collapsed materials from the overlying beds. Since the completion of the dam in 1984 the Mosul Dam personnel on-site have been engaged in a continuous high-maintenance foundation grouting program directed at filling voids and fractures created by dissolution and erosion of the underlying strata in the foundation [14].

Existing sinkholes seem to have first manifested themselves in 1992 and settled at a consistent rate until about 1998 when the rate of settlement reduced to around half or less of the initial rate. The maximum settlement measured was about $5 \mathrm{~m}$, and generally was between 3 to $3.5 \mathrm{~m}$. In areas where the sinkholes are located beneath the concrete pavement, the sunken concrete may be bridging over settled ground at a lower level (Figure 2). The average annual settlement is about $0.25 \mathrm{~m}$ per year [4].

First appearance of sinkholes on the right bank downstream was not until approximately seven years after the filling of the reservoir began. The surface expression of the sinkholes suggests that they are caused by an underground collapse. Concentric tension cracks appear to have developed around the central void as the sinkholes have developed progressively [3].

Three factors tend to dominate when sinkhole activity is initiated or increased. They are:

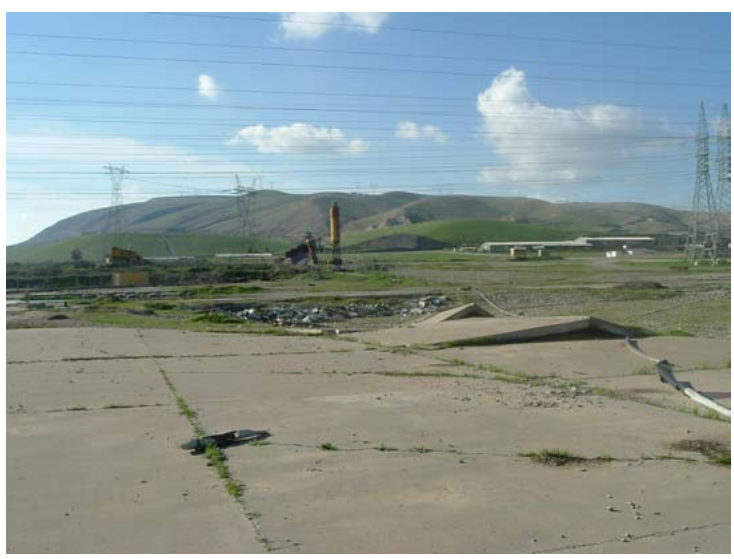

Figure 2. A sinkhole under a concrete pavement.
1) Increase of the infiltration rate of water on the ground surface.

2) Decrease of the groundwater piezometric level in the rock significantly below the soil-rock interface so as to provide an easy exit for the downward percolating water.

3) Repeated fluctuations of the groundwater from well above to well below the soil-rock interface that alternately saturates and drains the soil.

The appearance of the downstream sinkholes is most likely related to fluctuations in the tail water level of the main dam during operation of the dam and the downstream regulating reservoir [13]. It had been suggested that sinkholes may be connected to an aquifer on the right bank of the reservoir because before the reservoir was impounded, substantial flows of the order of 360 L/sec were encountered from a gypsum layer found during excavation of the tailrace tunnel for the pumped storage scheme; the water had a high sulphate content (which was different from the reservoir water).

Dissolution intensity at Mosul Dam ranged from 42 to 80 tons per day. This process coupled with the karstified limestone, dolomite, and calcareous marls as well as the evaporate rocks present the unfavorable foundation conditions under Mosul Dam. The karst line also denotes the transition from the interbedded limestone-anhydrite/ gypsum beds to the less permeable Jeribe limestone [14]. Examples of the types of karst conditions encountered during the excavation of the foundation are shown in Figures 3-5.

Karst area has high permeability conduits that convey substantial quantities of water at varying velocities. Karst development extends to a depth of about $100 \mathrm{~m}$ below the base of the dam. This may be a relict karst from a former climatic regime when groundwater levels were lower. The concerns in the limestone units are basically related to the existing caverns, voids, and fractures and not so much due to the erosion and dissolution process, as limestone generally dissolves at very slow rates. The main drawback to the site is the presence of soluble rocks by the presence of anhydrite and gypsum and the associated karst conditions at the foundation [3].

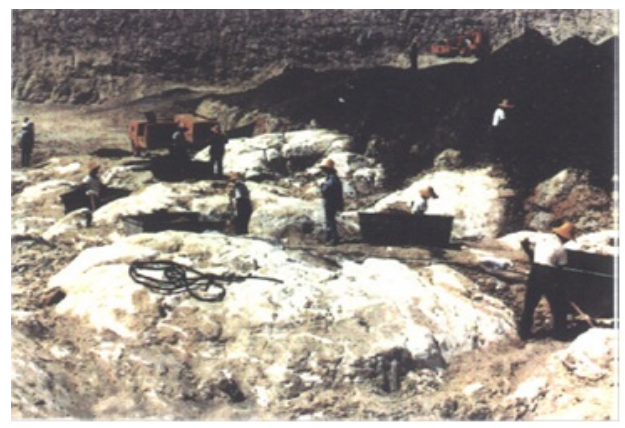

Figure 3. Karstified gypsum in the foundations of the dam. 


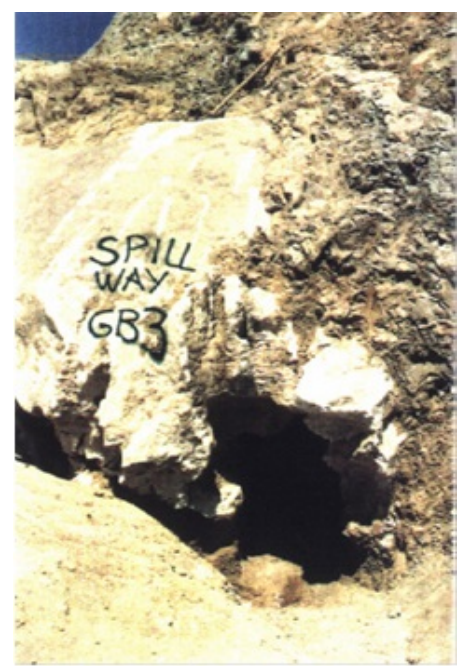

Figure 4. Karstfied gypsum in the foundations of the dam.

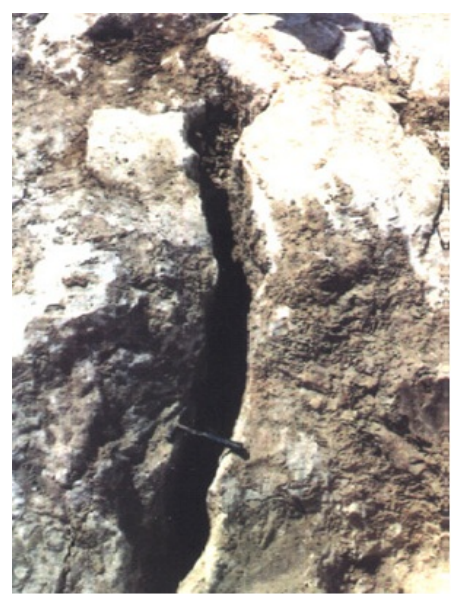

Figure 5. Solution crack.

Sinkholes on the right abutment have developed progressively with initial manifestation by surface cracking and ground settlement. By contrast, a sinkhole on the left flank of the reservoir in the local tourist village appeared without warning and developed rapidly with $15 \mathrm{~m}$ of settlement and a $15 \mathrm{~m}$ diameter depression overnight in February 2003 (Figure 6). The sinkhole was dry, located on a slope on the north side of a valley feature. The deposits at the surface standing vertically appear to be superficial silty soils, with perhaps bedded marls below. Although the initial sinkhole was filled with $1200 \mathrm{~m}^{3}$ of loose sandy gravel material and fenced off, the settlement continued. A further $3000 \mathrm{~m}^{3}$ of material was required to fill the settled surface of the sinkhole in two separate filling operations in May 2003 and October 2004. By March 2005 there were been a smaller settlement of the ground surface of about $0.5 \mathrm{~m}$.

It was reported that during the drilling of a piezometer hole near the sinkhole, a rod drop occurred. There was no water encountered in the hole so the piezometer was not

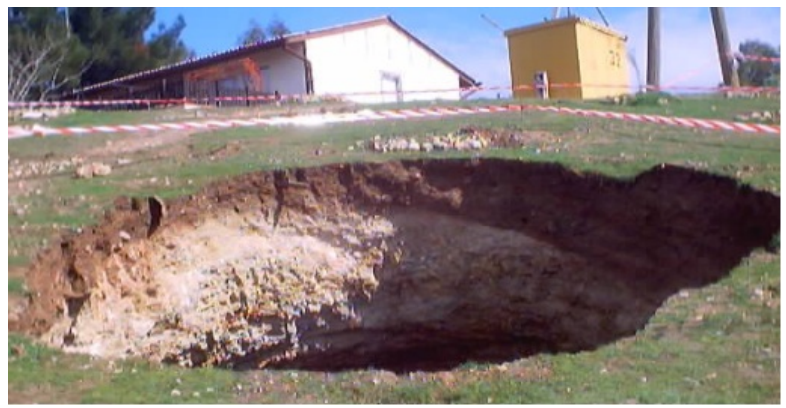

Figure 6. Sinkhole near the tourist village.

installed, and the hole was grouted, taking 250 tons of grout. The suggestion was been made that the sudden appearance of the sinkhole is related to seepage water passing through the left abutment of the reservoir and the sinkhole lies close to the end of the left extension of the original grout curtain. Though possible, an increase in infiltration of surface water, perhaps from heavy rain, could cause a collapse into an existing void by destabilizing the ground [13].

Ground movement or collapse may have been initiated by changes in groundwater consequent on impoundment of water in the regulating reservoir for those in the valley downstream of the main dam. The alignment of the sinkholes downstream of the dam strongly suggests a geological (structural) control and relatively near surface phenomenon. However, it has not been possible to verify this either by carrying out detailed geological field studies at the site or by obtaining high quality aerial photographs [3].

On the right abutment of the reservoir, about $100 \mathrm{~m}$ upstream from the dam, the ground surface on the slope formed on limestone on the margin of the reservoir had settled. This movement could be partly related to sloping failure and translation of the rock beds as a result of fluctuating reservoir levels and residual high pore pressures in the slope. However, a sinkhole feature seems more likely (Figures 7 and 8). Although tested for, no connection has been established between this upstream sinkhole and those downstream [14]. It is believed that, Figure 7 it is not a sinkhole, but a soil failure, which could be initiated due to over saturation of the soil by rain water and that of Figure 8 is slab failure, most probably due to fluctuation of the water level in the reservoir.

The prediction of sinkhole formation as well as the development of water bearing solution conduits beneath the embankment is obviously a critical issue. Previous surveys using echo sounding in the reservoir have reportedly not detected any evidence of sinkholes in the reservoir floor upstream of the dam. These surveys have established that sediment accumulation in the reservoir is limited to only about $1 \mathrm{~m}$. This helps to blanket the floor 


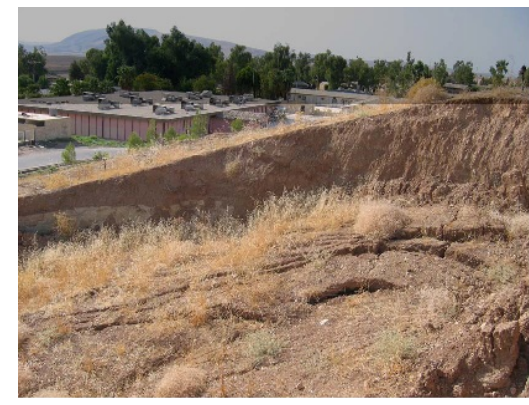

Figure 7. Soil failure in a village on left abutment.

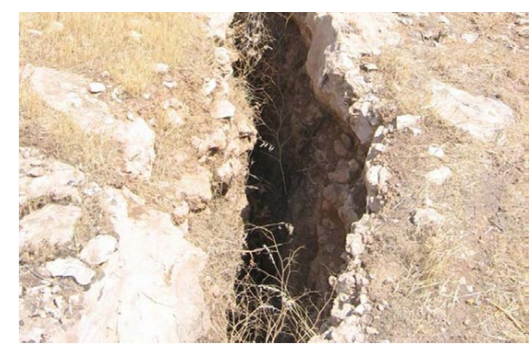

Figure 8. Upstream right abutment, open fissure resulting from slab slide.

of the reservoir and thus reduce inflow into the beds that might outcrop within the reservoir basin [4]. Hijab (2007), however, confirmed that some of the sinkholes are related to the reservoir. Their development is attributed to the development of underground conduits.

It is very clear from the aforementioned furnished data that the karstification in Mosul dam site is still active. It is also increasing in its activity causing a serious geological hazard to the status of the dam, if no relevant precautions are performed. This is also indicated from continuous grouting in the foundations of the dam. It is worth mentioning that by means of geophysical studies, it is possible to delineate the location of subsurface sinkholes [9]. Moreover, it is also possible to delineate the location of the subsurface channels (conduits) that are developed due to groundwater movement and dissolution of limestone and gypsum, which are the main rock types in Mosul dam site.

Issa et al. [10,12] conducted a bathymetric survey during 2011 and concluded that "After 25 years of the dam operation following; the thalweg bed slope of the River Tigris had changed from $0.65 \mathrm{~m} \cdot \mathrm{km}^{-1}$ before dam construction to $0.71 \mathrm{~m} \cdot \mathrm{km}^{-1}$ during the 2011 survey. The sedimentation rate in the upper section of the reservoir where the River Tigris enters the reservoir was greatest and gradually decreased toward the Mosul dam site. The greatest deposition thickness was $17.6 \mathrm{~m}$ in the upper zone of the reservoir. Furthermore, there are many areas like the middle and lower parts of the reservoir that are exposed to erosion. This is believed to be due to the dissolution of gypsum and limestone forming sinkholes that might reach about $20 \mathrm{~m}$ in diameter and $9.6 \mathrm{~m}$ in depth. This conducted survey also confirms the presence of sinkholes and other karst forms within the reservoir, which are active and continuously increasing in size, and exerting hazards to the Mosul Dam.

\section{Grouting}

Maintenance grouting of the foundation has been conducted continuously as a 24 hour per day, six days per week activity by Mosul Dam since 1988. The drilling, redrilling and grouting works, for the years 2002-2004 are tabulated in Table 1 . The total drilled holes for grouting and the amount of solid injected, for the years 1986-2003 are listed in Table 2.

Table 1. Aspects of drilling, redrilling and grouting works in Gallery, 2002-2004.

\begin{tabular}{ccccc}
\hline ITEM & 2002 & 2003 & 2004 & Total \\
\hline Drilling (m) & 37,216 & 22,827 & 26,550 & 86,593 \\
Grouting (m) & 36,823 & 22,848 & 26,493 & 86,164 \\
Redrilling (m) & 72,615 & 69,596 & 81,562 & 223,773 \\
Cement (tons) & 2704 & 2103 & 1945 & 6752 \\
Bentonite (tons) & 104 & 84 & 49 & 237 \\
\hline
\end{tabular}

Table 2. Meters drilling production and injected solids.

\begin{tabular}{|c|c|c|}
\hline Year & Total drilled (m ) & Injected solid ( tons ) \\
\hline 1986 & 20,248 & 3011 \\
\hline 1987 & 47,110 & 14,430 \\
\hline 1988 & 28,134 & 6759 \\
\hline 1989 & 53,559 & 6707 \\
\hline 1990 & 17,621 & 3680 \\
\hline 1991 & 13,971 & 6756 \\
\hline 1992 & 24,327 & 4736 \\
\hline 1993 & 21,496 & 4681 \\
\hline 1994 & 16,972 & 5287 \\
\hline 1995 & 13,546 & 4283 \\
\hline 1996 & 13,041 & 3749 \\
\hline 1997 & 19,192 & 2259 \\
\hline 1998 & 33,249 & 10,662 \\
\hline 1999 & 26,606 & \\
\hline 2000 & 20,744 & \\
\hline 2001 & 29,988 & \\
\hline 2002 & 37,217 & \\
\hline 2003 & 22,827 & \\
\hline
\end{tabular}


During this time, the lowermost anhydrite/gypsum transition zone has been the most troubling for grouting. Grout teams have returned to the same area many times to re grout the gallery three-line curtain. It has been reported that in some instances the same holes have been re drilled after several months and continued to accept grout. This is another clear indication for the activity of the karstification, causing another type of geological hazard, which is increasing the cost of the maintenance of the dam structure. Currently, the target depth for grouting is to terminate the grout curtain $20 \mathrm{~m}$ below the karst line at the Jeribe limestone in the right side of the dam and at the marl layers within the Fat'ha Formation in the middle and left side of the dam. Hole depths from the gallery through the transition zone into the Jeribe Formation are on the order of $100 \mathrm{~m}$. Evidence from the grouting program over the years suggests that the karst front in the transition zone stratum is migrating down dip, to the east [4], indicating the activity of the karstification.

The reasons behind the appearance of high permeability zones over the years of grouting are not clear. One explanation might be that the process of solution is opening up new water pathways or conduits within the rock. Solution of gypsum can take place relatively quickly, about ten times quicker than limestone. It is known that karst exists within the gypsum and this karst is often filled with weathered material. Such phenomenon is noted in karst features from Atshan Anticline, SE of the Mosul dam site [20]. So another possible explanation is that any weak weathered matrix material infilling the karst is being washed out from between sound rock and this creates open conduits. This explanation appears to fit with many observed features [14].

Given the long grouting program and the substantial volumes of grout that must have been placed the question must be; where did the grout go? Several possibilities can be considered, such as:

- Wash out of the grout during placing.

- Wash out of the grout before it has set and hardened.

- Aggressive attack on the grout by sulphate rich water causing disintegration and subsequent wash out.

- Chemical changes to the bentonite causing disintegration of the grout allowing it to be washed away.

- The grout has remained in place and new solution channels form around it, as a result of shrinkage and the tendency of water to flow at the interface of contrasting materials.

- Some loss due to wastage.

- Some loss when drilling out existing holes.

\section{Evaluation of the Existing Conditions}

Karstification, which is one of the main geological hazards not only in the dam site, but also in Iraq, is the main dangerous feature that causes a serious problem to the stability of Mosul dam.

Existing conditions of Mosul Dam were evaluated by different teams using the information available at different times. The embankment and structures appear to be well designed and stable; the principal concerns are related to the foundation and the associated continuous grouting program, the presence of sinkholes in the vicinity of the dam, the foundation monitoring program, and the scour at the bottom outlet plunge pool. In addition, the leaks in the spillway area were also discussed and require remediation to decrease the current leakage $[3,4,13,14]$.

\subsection{Dam and Reservoir}

The main dam looks to be in good condition. The crest appears uniform. The line and level of the upstream face appears uniform based on the visible water line. The downstream face shows no obvious indications of distress.

\subsection{Grouting}

Inspection of the grouting gallery shows that it is in good condition. The gallery is D shaped, $3.70 \mathrm{~m}$ high and 3.40 $\mathrm{m}$ wide with concrete walls and crown typically $1 \mathrm{~m}$ thick and concrete floor $1.70 \mathrm{~m}$ thick. The roof, walls and floor generally seemed to be dry. Although the drilling and grouting exercise has been carried on almost continuously since the end of construction almost 20 years ago, significant grout takes are still encountered. In 1998, a single newly drilled hole had a consumption of 3000 tons of cement. In another, 6747 tons of the mixture was used in one stage in a single hole, which took 24 days to inject. Grouting is usually indicated where flow from the drill-hole is more than $75 \mathrm{~L} /$ minute from a $5 \mathrm{~m}$ section. However, much larger flows have been recorded including flow from one hole of $1500 \mathrm{~L} /$ minutes.

\subsection{Existing Conditions}

The dam has been extensively studied in the past, and the geology has not fundamentally changed. It is therefore, important to establish the initial foundation conditions and develop the geological model, then to determine what changes may have taken place to it since construction.

Mark and Wheeler and Washington Group Int. [3,13] proposed the following scenario for Mosul dam collapse: The City of Mosul is located about $60 \mathrm{~km}$ downstream of Mosul Dam. Analyses indicate that failure of Mosul Dam would produce a flood wave crest about $20 \mathrm{~m}$ deep in the City of Mosul. It is estimated that the leading edge of the failure flood wave would arrive in Mosul about 3 hours after failure of the dam, and the crest of the flood wave would arrive in Mosul about 9 hours after failure of the 
dam. The total population of the City of Mosul is about 3 million, and it is estimated that about 2 million people are in locations within the city that would be inundated by a $20 \mathrm{~m}$ deep flood wave. The City of Baghdad is located about $350 \mathrm{~km}$ downstream of Mosul Dam, and the dam failure flood wave will arrive after 72 hours to Baghdad and would be about $4 \mathrm{~m}$ deep.

\section{Conclusions and Recommendation}

\subsection{Conclusions}

1) The presence of layers of gypsum, anhydrite, and limestone throughout the foundation provides materials susceptible to solution and erosion over the short and long term.

2) The main concern was related to the dissolution of gypsum in the foundation and the continuous maintenance grouting program. The cause of the problem was investigated and related to the construction of the dam taking place without fully addressing the foundation concerns that were known from that time. This was further compounded by failing to achieve grout curtain closure before the reservoir commenced to fill.

3) Sinkholes do not appear to pose an instability concern for the dam at the present time, but there is no guarantee that such cavities are not present under the embankment; additional studies and monitoring should be performed. Moreover, they are clear indication for the activity of the karstification.

4) Voids or conduits formed at or close to the base of the embankment would provide conditions favorable to the formation of sinkholes in the dam and/or piping conditions resulting in the erosion of the core and filters.

5) The recent examples of sinkhole activity are indications that abrupt offsets due to subsidence and sinkhole formation are real features and threats at this site.

6) The continuous grouting and re-grouting is another clear indication for the activity of the karstification.

\subsection{Recommendations}

1) The completion of Badush Dam, a partially completed structure approximately $40 \mathrm{Km}$ downstream of Mosul Dam, is therefore, the only measure, which can reasonably be taken to reduce the risk to downstream populations to acceptable values. A completed Badush Dam would act as a backstop structure in the event that the Mosul Dam foundation deteriorates to the point that the reservoir cannot be retained. Badush Dam was originally designed for this purpose and should be completed as soon as possible. The structure is currently about $40 \%$ complete with some elements within the structure closer to completion than others.

2) The so-called maintenance grouting program must be continued to preserve the considerable investment at Mosul dam site and to prevent, to the degree possible, the loss of the reservoir.

3) Execution of a detailed geological mapping, at scale of 1:5000, accompanied with relevant geophysical and hydrogeological studies for the dam site; in order to:

- Delineate the exposed rock types at the dam site and follow their extensions.

- Detect the karstification forms that exist in the dam site and discover their origin, activity and extensions.

- Detect any structural disturbances for the rocks, as faults, major joints, and weakness zones and to assess their effect on the stability of the dam.

- Detect active geological hazards at the dam site and assess their impact upon the stability of the dam.

- Execution of geophysical measurements to confirm the discovered karst and weakness zones and delineate their subsurface extensions.

- Drilling of few boreholes to confirm the critical hazardous areas that effect upon the stability of the dam.

\section{Acknowledgements}

The author would like to express his sincere thanks to the authorities of Mosul Dam Operation Office, especially to Mr. Abdul Khaliq Dhanoon the Director of the Operation Office (2009) for providing the assessment reports, without those reports this report wouldn't be completed. The research presented has been financially supported by Luleå University of Technology, Sweden and by "Swedish Hydropower Centre-SVC" established by the Swedish Energy Agency, Elforsk and Svenska Kraftnät together with Luleå University of Technology, The Royal Institute of Technology, Chalmers University of Technology and Uppsala University. Their support is highly appreciated.

\section{REFERENCES}

[1] Ministry of Water Resources Iraq, "Water Resources," Mosul Dam, 2012. http://www.mowr.gov.iq:81/arabi/

[2] Imatran Voima Osakeyhtio, "Consulting Engineers, Finland. Hydrological and Reservoir Information,” Ministry of Agrarian Reform, Republic of Iraq, 1968.

[3] Mark and Wheeler, "Mosul Dam Assessment Task Order No. 8," Report on Site Visit, Mosul Dam Library, 3-7 September 2004.

[4] Black and Veatch, "Mosul Dam Assessment," Review of 1984 Dambreak and Floadwave Study for Mosul Dam, Mosul Dam Library, Iraq, 2004.

[5] N. A. Al-Ansari, A. Barazanji, M. Al-Jabbari and A. Gayara, "Geological Investigation of Mosul Dam Site," Cofidential Report, Ministry of Irrigation, 1984, 39 p.

[6] J. M. Tawfiq and J. Domas, "Report on the Regional Geological Mapping of Ain Zala-Butmah-Dohuk Area," GEOSURV, 1977. 
[7] V. K. Sissakian and F. A. Ibrahim, "Geological Hazards Map of Mosul Quadrangle, Scale 1:250000,” GEOSURV, 2004.

[8] S. R. Hijab and M. A. Al-Jabbar, "Geophysical Investigation on Mosul Dam Area, Stage One. Emergency Microgravity Survey,” GEOSURV, 2006.

[9] B. R. Hijab, A. S. O. Al-Qadir and A. S. Musa, "Geophysical Investigation on Mosul Dam, Second Stage. Detailed Geophysical Survey,” GEOSURV, 2007.

[10] E. I. Issa, N. Al-Ansari and S. Knutsson, "Changes in Bed Morphology of Mosul Dam Reservoir," Journal of Advanced Science and Engineering Research, Vol. 3, No. 2, 2013, pp. 86-95.

[11] N. A. Al-Ansari, E. I. Issa and S. Knutsson, "Nature of the Distributed of the Bed Sediment within Mosul Dam Reservoir, Iraq,” 2nd Engineering Scientific Conference, Mosul University, Mosul, 19-20 November 2013.

[12] E. I. Issa, N. A. Al-Ansari and S. Knutsson, “Assessment of Sedimentation Characteristics and Capacity Curve for Mosul Dam Reservoir, Iraq,” 2nd Engineering Scientific Conference, Mosul University, Mosul, 19-20 November 2013.

[13] Washington Group International, "Inter-Office Correspondence,” Mosul Dam Library, 2005.
[14] D. A. Bruce, "Synopsis for Review Meeting in Amman, Jordan, January 24-26, 2005,” Mosul Dam Library, 2005.

[15] N. Al-Ansari, E. I. Issa, G. H. Shirwani and S. Knnutson, "Sedimentation in the Mosul Reservoir of the Northern Iraq,” Journal of Environmental Hydrology, Vol. 21, 2013. http://www.hydroweb.com

[16] E. I. Issa, N. Al-Ansari and S. Knutsson, "Sedimnetation and New Operational Curves for Mosul Dam, Iraq,” $\mathrm{Hy}$ drogeological Science Journal, Vol. 58, No. 7, 2013, pp. 1456-1466. http://dx.doi.org/10.1080/02626667.2013.789138

[17] V. K. Sissakian, D. H. Hagopian and Kh. A. Ma’ala, "Geological Map of Mosul Quadrangle, Scale 1: 250000,” GEOSURV, Baghdad, 1995.

[18] V. K. Sissakian, "Geological Map of Iraq, Scale 1:1000000," 3rd Edition, GEOSURV, Baghdad, 2000.

[19] V. K. Sissakian and H. A. Al-Mousawi, "Karstification and Related Problems in Iraq," Iraqi Bulletin of Geology and Mining, Vol. 3, No. 2, 2007, pp. 1-12.

[20] V. K. Sissakian and M. F. Abdul Jabbar, "Site Selection Problems in Gypsum Bearing Areas," Iraqi Bulletin of Geology and Mining, Vol. 1, No. 2, 2005, pp. 45-52. 